\title{
RESEARCH PAPER \\ Methodology for determining the suitability of land for the cultivation of highbush blueberry: a case study on a farm in southern Chile
}

\section{Leonardo Vera ${ }^{1}$, René Montalba ${ }^{2}$, Lorena Vieli ${ }^{2}$, Emilio Jorquera $^{3}$, and Isabel González ${ }^{4}$}

\begin{abstract}
${ }^{1}$ Departamento de Ecología y Biodiversidad, and Center for Sustainability Research, Facultad de Ecología y Recursos Naturales, Universidad Andrés Bello. República 440, Santiago, Chile.

${ }^{2}$ Instituto del Medio Ambiente, and Departamento de Ciencias Agronómicas y Recursos Naturales, Universidad de La Frontera. Casilla 54-D, Temuco, Chile.

${ }^{3}$ Programa de Doctorado en Ciencias de Recursos Naturales, Facultad de Ingeniería y Ciencias, Universidad de La Frontera. Casilla 54-D, Temuco, Chile.

${ }^{4}$ Centro Regional de Innovación Hortofrutícola de Valparaíso-Pontificia Universidad Católica de Valparaíso. San Francisco s/n La Palma, Quillota, Chile.
\end{abstract}

\begin{abstract}
L. Vera, R. Montalba, L. Vieli, E. Jorquera, and I. González. 2015. Methodology for determining the suitability of land for the cultivation of highbush blueberry: a case study on a farm in southern Chile. Cien. Inv. Agr. 42(3): 353-364. The selection of good planting sites is critical for the success of blueberry plantations. The objective of the present study was to identify farm territorial units suitable for the establishment and management of highbush blueberry crops on a farm in southern Chile. A farm-level characterization was developed, and districts and sites were classified according to their receptive capacity. Numerical suitability values were subsequently obtained for each land unit identified on the farm. Four suitability categories were identified on the farm: high, moderate, low, and unsuitable, and they corresponded to 12, 60, 20, and $7 \%$ of the total surface area, respectively. The main limitations for blueberry cultivation were steep slopes, shallow soil, hydromorphism, and a soil $\mathrm{pH}$ that greatly exceeded the low $\mathrm{pH}$ values required for blueberry crops. The methodology revealed that blueberry cultivation is possible on $72 \%$ of the total surface area of the farm (high and moderate suitability areas) provided that soil management measures corresponding to the specific limitations of each area are used.
\end{abstract}

Key words: Landscape management, limiting variable, $\mathrm{pH}$, receptive capacity, slope.

\section{Introduction}

Northern highbush blueberry (Vaccinium corymbosum L.) is a deciduous fruit native to the cool temperate forests of North America. The species was introduced into Chile in 1979. Since

Received October 24, 2014. Accepted August 31, 2015. Corresponding author: leonardo.vera@unab.cl then, the area used for the cultivation of northern highbush blueberry has rapidly increased due to the attractive profit potential of the fresh export market (Buzeta, 1997). In Chile, the total area under blueberry cultivation is 9,940 ha (Instituto Nacional de Estadísticas, 2007).

The selection of good planting sites is critical for the success of blueberry plantations. From a 
macroscale perspective, the climatic conditions in southern Chile are ideal for the cultivation of highbush blueberry. The thermal accumulation exceeds 800 degree-days using a base temperature of $10^{\circ} \mathrm{C}$, while the chilling hours range from 700 to 1000 depending on the latitude. Moreover, the annual precipitation exceeds $800 \mathrm{~mm}$ and occurs primarily during the winter months. It should be considered, however, that in recent years, there has been a severe water shortage in the area, which has appeared in the last three years with a rainfall deficit between 11 and 44\% (the Rivers area region was declared an agricultural emergency in March 2015 by the Agriculture Subsecretariat-Resolution No. 97/2015) (Ministerio de Agricultura, 2015). As a result, there is insufficient snow accumulation in the high mountain to ensure irrigation water supply for the crops.

Nevertheless, macroscale data alone are insufficient for predicting the success of a crop on any given farm, and it is necessary to analyze crop suitability at the farm level (Gastó et al., 2012; Robinson et al., 2009). The determination of receptive capacity reflects this level of analysis and is a measure of the capacity of land to receive and assimilate an amount of technological input without a reduction in productive capacity (Ande, 2011).

Within a farm, some land units are highly suitable for crop production and have minimal economic and environmental costs, while other land units are less suitable and thus incur high costs. For example, crop establishment costs are higher in mountainous areas because of the investment required for erosion control methods (terraces, infiltration furrows, and erosion-control plants), fertilization, and increasing the effective soil depth (Calatrava et al., 2007).

The determination of the receptive capacity of a land unit requires consideration of the key characteristics of a given natural system and the hierarchical prioritization of these characteristics (Beare et al., 1995). Higher-level characteristics are those that cannot be modified and exhibit a broad territorial influence beyond the scale of the farm. They include macroscale variables such as climate, precipitation, and altitude. At a farm scale, the landform is the highest-ranked characteristic because it exerts a direct influence over other factors such as the microclimate, humidity, and soil drainage (Basheer-Salimia et al, 2014; Ande, 2011). Physical soil characteristics that are difficult to modify, particularly texture, depth, and drainage, are the next highest determinants of agricultural suitability (Steubing et al., 2002; Shepherd, 2000). The lowest-ranked characteristics are those that are highly variable and easily affected by common agricultural practices. These characteristics include $\mathrm{pH}$, fertility, stoniness, organic matter content, and plant cover, and should be incorporated into the determination of suitability if they have a restrictive effect on the evaluated crop (López et al., 2006; Vélez and Gastó, 2002).

A number of studies have established multicriteria methodologies for quantifying farm suitability (USDA, 2003, Shepherd, 2000). Vélez and Gastó (2002), for example, developed a simple method for evaluating districts and sites according to their receptive capacity. This methodology and others (López et al., 2006; Shepherd, 2000) integrate various indicators (landform, texture, depth, chemical and organic variables of soil quality, among others) and produce a numerical value that corresponds to a defined agricultural suitability class (high, restricted, low, and very low) for each land unit. Ultimately, the methods allows for the identification of agriculturally suitable land blocks within a farm. The methods proposed by Vélez and Gastó (2002) and Shepherd (2000) can be adapted for the cultivation of northern highbush blueberry because they incorporate factors that are critical for the cultivation of this species. In the case of blueberry cultivation, these factors are soil $\mathrm{pH}$, organic matter content and concentrations of nitrogen, phosphorus, and calcium (ShanShan et al., 2009).

The objective of the present study was to identify blocks of land suitable for the establishment and 
management of a blueberry crop on a farm in southern Chile. The specific objectives of this study were to define homogeneous land blocks to characterize the site; characterize the property based on the determination of variables related to the territorial suitability for the cultivation of blueberries; discretize, weight and integrate the information obtained for the variables and thus obtain unique values of land suitability for each block characterized; define blocks with high and low suitability for the cultivation of blueberry based on the final score, and identify the main constraints in land blocks with low suitability.

\section{Materials and methods}

\section{Study area}

The farm covers an area of 47.54 ha and is located near Riñihue (UTM 719800 E; 5594500 N) in the commune of Los Lagos, in the central zone of the Los Ríos region in Chile (Figure 1). Natural meadows and annual crop stubble fields characterize the plant cover of this zone. The climate of the region is humid temperate with cool and generally dry summers, typical of the Llanquihue zone. In the interior of the region, rainfall varies between $1235 \mathrm{~mm}$ and $2000 \mathrm{~mm}$. The average annual temperature ranges between $10^{\circ} \mathrm{C}$ and 12 ${ }^{\circ} \mathrm{C}$. However, in summer, the average monthly temperature increases to between $16^{\circ} \mathrm{C}$ and 17 ${ }^{\circ} \mathrm{C}$ (Instituto Nacional de Estadísticas, 2007). The soils of the study area are Andisols of the Lanco series. They are characterized as being very thin with slopes of 1-30\%, moderately coarse textures, a granular surface structure and sub-angular blocks at depth, good physical properties and a high percentage of organic matter. They are acidic at the soil surface and slightly acid at depth, with poor fertility, and contain ash from recent volcanic activity. They are generally classified as land use capacity III to VI soils, a classification indicating limited crop suitability (Centro de Información de Recursos Naturales, 2002).

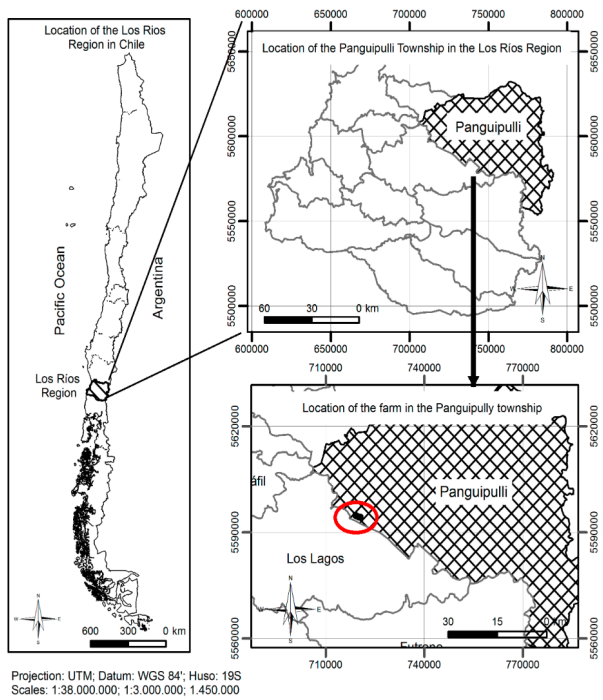

Figure 1. Geographic location of the study area.

\section{Data collection and analysis}

The biogeological structure of the study area was characterized using photographic analysis, land survey information, and a geographical information system (GIS) that permitted the management and visual representation of the data. ArcGIS 9.3 software (ESRI Inc. 1999-2008) was used for the analysis.

For the preliminary location of the farm and its surroundings at the commune scale, a map of Riñihue (code G 121, scale 1:50,000, Instituto Geográfico Militar, IGM) was used. Stereoscopic analysis and aerial photographs of the zone were used to demarcate the biogeological structural units present on the farm, which corresponded to areas homogeneous in color, tone, and texture. The analysis was performed using FONDEF 1995 (SAF) aerial photos 53890-53891 (scale 1:20,000). The biogeological units were subsequently characterized according to their field descriptions and measurements (Gastó, et al., 2002; Vélez and Gastó, 2002).

The photographically analyzed land units were digitized using an IGM orthophoto (section G Riñihue; scale 1:20,000; transverse Mercator 
projection datum SUD 69, Huso 19) and ArcGIS 8.3 software (1999, California, USA), and the data were transformed to datum WGS 84'. The digitization of the land units provided a layer of information integrated within a database. Suitability data and information collected on the ground for each variable and land unit were subsequently entered into the database.

\section{Farm characterization methods}

The characterization of the farm was performed according to the ecorregion classification described by Gastó et al. (2002). This method is based on the decomposition of the actual or original ecosystem into internal and external subsystems, and aims to minimize the complexity of the analysis and to facilitate decision-making (Robinson et al., 2009; Wu and David, 2002). In accordance with the objective of this investigation, only the biogeological structure was characterized. This subsystem corresponds to natural resource elements, such as soil, vegetation, and geological and geomorphological formations, on each land unit of the farm (López et al., 2006; Shepherd, 2000). The characterization of the biogeological structure and soils permitted the application and adaptation of the methodology described by Vélez and Gastó (2002) for the identification of land blocks suitable for blueberry cultivation.

For the characterization of the biogeological structure at the farm level, both high- and lowranking variables in the hierarchy were considered. The landform variable, a high-priority variable at the farm level, was characterized by district classification. Districts correspond to the slope of the terrain and can be separated into six classes of slope percent grades (Cosio et al., 2007; López et al., 2006) (Table 1). The grades were determined using a manual field clinometer (Suunto PM 5-360).

High- and low-ranking edaphic variables were incorporated into the site indicator, which includes a two-digit code representing texture-depth and hydromorphic characteristics (Table 1). If another limiting variable was also present within a biogeological structural unit, that particular variable was also incorporated into the site indicator.

Texture and hydromorphism were discretized into nine classes using the classification method described by Gastó et al. (2002) (Table 1), and each class was assigned a number to facilitate on-site characterization.

The soil chemical variables that were considered limiting for the establishment and development of northern highbush blueberry were $\mathrm{pH}$, organic matter, nitrogen $(\mathrm{N})$, phosphorus $(\mathrm{P})$, and calcium (Ca). These variables were discretized into four classes using previously described classification schemes (Broll et al., 2005; Food and Agriculture Organization of the United Nations, 2006) (Table 2). In the case that one of these variables was found to have a limiting effect on blueberry cultivation, it was incorporated into the site indicator with a letter identifying the variable and a digit indicating its value (adapted from Gastó et al. 2002).

According to the characterization methods described above, a site indicator with the code 79 pH 2 corresponds to a deep soil with light texture, fast drainage, and an extremely acidic $\mathrm{pH}$ (see codes on Tables 1 and 2).

\section{On-site measurements and descriptions}

The following steps were used for the determination of the field sites:

- Localization of the biogeological structural units (based on photographic analysis).

- Boring to a depth (soil sampler) of 1.2-1.5 m to determine the effective soil depth.

- Determination of the texture by touch at the effective depth and characterization of hydromorphism. Texture was determined 
Table 1. Discretization of the district, texture-depth and hydromorphic variables and assignment of suitability values for the establishment and development of northern highbush blueberry based on Table 4 .

\begin{tabular}{clc}
\hline Class number & & Suitability value \\
\hline District class & & \\
1 & Depression & 0.25 \\
2 & Flat (0-10.5\% slope) & 0.75 \\
3 & Softly undulating (10.5-17.5\% slope) & 1 \\
4 & Inclined undulating (17.5-34.5\% slope) & 0.75 \\
5 & Hilly (34.5-66\% slope) & 0.5 \\
6 & Mountainous (>66\% slope) & 0.25
\end{tabular}

Site class

\begin{tabular}{lll}
\multicolumn{2}{l}{ Texture-depth class } \\
1 & Light-shallow & 0.25 \\
2 & Medium-shallow & 0.50 \\
3 & Heavy-shallow & 0.25 \\
4 & Light-intermediate & 0.50 \\
5 & Medium-intermediate & 0.75 \\
6 & Heavy-intermediate & 0.25 \\
7 & Light-deep & 0.75 \\
8 & Medium-deep & 1.00 \\
9 & Heavy-deep & 0.25 \\
& Hydromorphism class & \\
1 & Permanent surface hydromorphism & 0.25 \\
2 & Permanent mid-level hydromorphism & 0.25 \\
3 & Permanent deep hydromorphism & 0.50 \\
4 & Seasonal surface hydromorphism & 0.25 \\
5 & Seasonal mid-level hydromorphism & 0.50 \\
6 & Seasonal deep hydromorphism & 0.75 \\
7 & Slow drainage & 0.75 \\
8 & Moderate drainage & 1.00 \\
9 & Fast drainage & 0.75 \\
\hline
\end{tabular}

Adapted from Gastó et al. (2002) and López et al. (2006). Texture: medium = loose; light $=$ sandy; heavy $=$ clayey. Depth: shallow $=0-30 \mathrm{~cm}$; intermediate $=30-80 \mathrm{~cm}$; deep $=>80 \mathrm{~cm}$.

Table 2. Discretization of site variables: $\mathrm{pH}$, organic matter, phosphorus, and calcium. Variables and assignment of suitability values for the establishment and development of northern highbush blueberry based on Table 3 .

\begin{tabular}{|c|c|c|c|c|c|c|}
\hline \multirow[b]{2}{*}{$\begin{array}{c}\text { Class } \\
\text { number }\end{array}$} & \multicolumn{6}{|c|}{ Soil Chemical Variable } \\
\hline & $\mathrm{pH}$ & $\begin{array}{c}\text { Organic matter } \\
(\%)\end{array}$ & $\begin{array}{l}\text { Available P } \\
\left(\mathrm{mg} \mathrm{kg}^{-1}\right)\end{array}$ & $\begin{array}{c}\mathrm{Ca} \\
\left(\mathrm{mg} \mathrm{kg}^{-1}\right)\end{array}$ & $\begin{array}{l}\text { Available N } \\
\left(\mathrm{mg} \mathrm{kg}^{-1}\right)\end{array}$ & $\begin{array}{l}\text { Suitability } \\
\text { value }\end{array}$ \\
\hline 1 & $4.5-5$ Very acidic & $>3 \%$ High & $11-15$ Normal & $5-8$ Normal & $21-40$ Normal & 1 \\
\hline 2 & $\begin{array}{l}4-4.4 \text { Extremely acidic } \\
5-5.5 \text { Strongly acidic }\end{array}$ & $2-3 \%$ Normal & $\begin{array}{l}16-18 \text { High } \\
6-10 \text { Low }\end{array}$ & $\begin{array}{l}8-15 \text { High } \\
2-4 \text { Low }\end{array}$ & $\begin{array}{l}41-45 \text { High } \\
16-20 \text { Low }\end{array}$ & 0.75 \\
\hline 3 & $\begin{array}{l}3.5-4 \text { Extremely acidic } \\
5.5-6.0 \text { Moderately acidic }\end{array}$ & $1-2 \%$ Low & $\begin{array}{l}19-20 \text { Very high } \\
2-5 \text { Very low }\end{array}$ & $\begin{array}{l}16-20 \text { Very high } \\
1-2 \text { Very low }\end{array}$ & $\begin{array}{l}46-50 \text { Very high } \\
10-15 \text { Very low }\end{array}$ & 0.5 \\
\hline 4 & $\begin{array}{l}<3.5 \text { Ultra acidic } \\
>6.0 \text { Mildly acidic to } \\
\text { alkaline }\end{array}$ & $<1 \%$ Very low & $\begin{array}{l}>20 \text { Very high } \\
<2 \text { Very low }\end{array}$ & $\begin{array}{l}>20 \text { Very high } \\
<1 \text { Very low }\end{array}$ & $\begin{array}{l}>50 \text { Very high } \\
<10 \text { Very low }\end{array}$ & 0.25 \\
\hline
\end{tabular}


using the touch method, i.e., rubbing the sample between the fingers to assess whether it was rough or smooth, and adding water to assess the malleability and soapiness of the sample. Hydromorphism was characterized qualitatively by the presence of moisture and dappling, which are characteristics of the iron and manganese oxides formed by alternation between reductive and oxidative conditions in the soil (Perverzev and Litvinova, 2008; Shepherd, 2000).

- Collection of soil samples from the top $30 \mathrm{~cm}$ of each site of the farm.

- Laboratory analysis of the samples for the soil chemical variables that were found to be critical for the cultivation of northern highbush blueberry: $\mathrm{pH}$, organic matter, nitrogen $(\mathrm{N})$, phosphorus $(\mathrm{P})$, and calcium $(\mathrm{Ca})$.

\section{Chemical analysis of the soil}

Soil samples were analyzed to evaluate the following chemical factors, which were found to have a limiting effect on the cultivation of blueberry: $\mathrm{pH}$ and $\mathrm{N}, \mathrm{P}, \mathrm{Ca}$, and organic matter contents (Table 2). All of these variables were determined using routine methodology. $\mathrm{pH}$ was determined by suspension and potentiometric analysis. Calcium was determined by extraction with ammonium acetate followed by absorption spectrophotometry. Phosphorus was determined by extraction with sodium bicarbonate solution. Organic matter was determined by oxidation with sodium dichromate in an acidic medium and subsequent colorimetric determination. Finally, nitrogen was determined by Kjeldahl digestion (Sadzawka et al,. 2006).

\section{Determination of suitability}

A numerical suitability value, between 0 and 1 (Tables 1-2), was assigned to each of the characterization classes (district, site, hydromorphism and soil chemical variables). The analyzed variables were discretized into these classes adapting the methodologies described by López et al., 2006; Vélez and Gastó (2002) and Shepherd (2000). Values were assigned by comparing the requirements for the establishment and cultivation of northern highbush blueberry (Reyes-Díaz et al., 2009; ShanShan et al., 2009) (Table 3) with the values of each class for each variable.

The determination of the suitability of the biogeological structural units was adapted from the methodology described by Vélez and Gastó (2002) and Shepherd (2000). The following formula was used to calculate the suitability value for each biogeological structural unit (adapted from USDA, 2003; Shepherd, 2000):

Suitability value of biogeological structural unit $=$ District suitability value $($ Table 1$) \times 0.6+$ site suitability value $\times 0.4$

where:

Site suitability value $=$ Texture-depth suitability value $($ Table 1$) \times 0.4+$ hydromorphism suitability value $($ Table 1$) \times 0.4+$ critical variable suitability value (Table 3$) \times 0.2$

Finally, a qualitative descriptor was assigned to each range of suitability values:
Unsuitable:
$<0.45$
Low suitability:
$0.45-0.66$
Moderate suitability:
$0.67-0.84$
High suitability:
$>0.84$ 
Table 3. District and site requirements for the establishment of northern highbush blueberry, according to Reyes-Díaz (2009) and ShanShan et al. (2009).

\begin{tabular}{|c|c|c|}
\hline Indicator & Variable & Acceptable range for blueberry cultivation \\
\hline District & Slope & $\begin{array}{l}\text { Preferably light relief }(10-17.5 \%) \text { terrain approximately } 20 \mathrm{~m} \text { from the foot of the slope } \\
\text { Frosts occur frequently on soils in flat areas, while sloped terrain permits cold air to flow } \\
\text { downward. } \\
\text { Meadow soils are not suitable for this species because of frequent waterlogging, which } \\
\text { compromises the root system. The high oxygen demand of this species during its annual } \\
\text { growth cycle and its sensitivity to the toxic effects of soluble manganese and oxygen } \\
\text { compounds contribute to its susceptibility to waterlogging. }\end{array}$ \\
\hline \multirow[t]{7}{*}{ Site } & Texture & Loose to loose-sandy soils (medium texture) \\
\hline & Depth & $\begin{array}{l}\text { Intermediate to deep } \\
\text { Highbush blueberry roots reach } 60-80 \mathrm{~cm} \text {. }\end{array}$ \\
\hline & Hydromorphism & $\begin{array}{l}\text { Moderate drainage } \\
\text { The species is adapted to drought stress over short periods but does not tolerate flooding, } \\
\text { which results in root death. }\end{array}$ \\
\hline & $\mathrm{pH}$ & $\begin{array}{l}\text { Acidic }(\mathrm{pH} 4.3-5) \\
\text { A soil } \mathrm{pH} \text { above } 5.2 \text { may create iron deficiency problems in the plants, manifested as } \\
\text { chlorosis. } \\
\text { At extremely acidic } \mathrm{pH} \text { values }(<4) \text {, high aluminum }\left(\mathrm{Al}^{3+}\right) \text { levels have been shown to } \\
\text { reduce the photosynthetic efficiency of certain blueberry cultivars under laboratory } \\
\text { conditions. }\end{array}$ \\
\hline & Organic matter & $\begin{array}{l}\text { High (3-5\%) } \\
\text { A high percentage of organic matter retains moisture and nutrients, particularly iron } \\
\text { (Fe); serves as an energy source for beneficial microorganisms; increases soil porosity; } \\
\text { and limits the accumulation of phytotoxic Al species by promoting the retention of Ca, } \\
\text { potassium, and magnesium. }\end{array}$ \\
\hline & Calcium & $\begin{array}{l}\text { Normal }\left(5-8 \mathrm{mg} \mathrm{kg}^{-1}\right) \\
\text { Excess Ca leads to Fe deficiencies. }\end{array}$ \\
\hline & Phosphorus and nitrogen & $\begin{array}{l}\text { Normal (11-15 and } 21-40 \mathrm{mg} \mathrm{kg}^{-1} \text { of } \mathrm{P} \text { and } \mathrm{N} \text {, respectively) } \\
\text { The species is sensitive to overfertilization. Among the forms of } \mathrm{N} \text {, the plant is sensitive } \\
\text { to excess nitrate, which raises the } \mathrm{pH} \text {. }\end{array}$ \\
\hline
\end{tabular}

The suitability values were used to create the final suitability map of the farm.

\section{Results and discussion}

\section{Farm characterization}

Districts. Approximately $32 \%$ of the 47.54 -ha land area was classified as inclined undulating. A smaller percentage of the area was classified as softly undulating $(21 \%)$ or flat $(20 \%)$. Hilly, depressed, and mountainous districts occupied smaller areas (Figure 2).

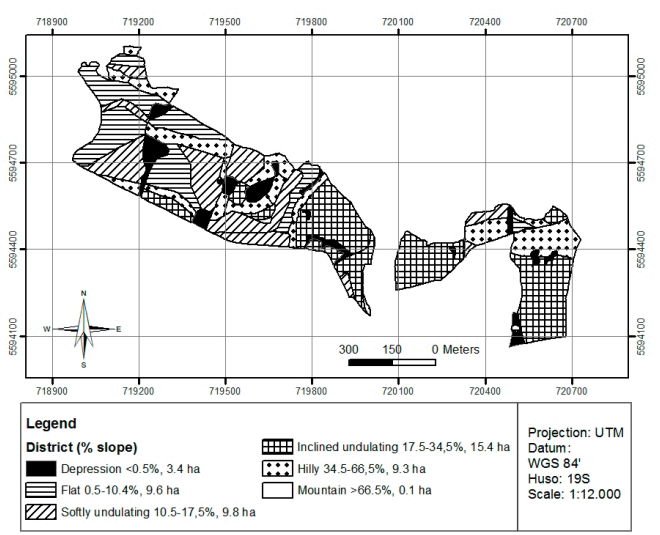

Figure 2. Districts in the study area. 
Sites. Seven sites were defined, classified according to their texture, depth, and hydromorphic characteristics (Figure 3, Table 4). All of the sites were found to have soils with medium texture (loam soil), variable depth (shallow to deep), and good drainage or seasonal hydromorphism in different strata. Moreover, the $\mathrm{pH}$ was moderately acidic $(5.5-6)$ at all sites. Because the cultivation of northern highbush blueberry requires high acidity, $\mathrm{pH}$ was incorporated into the site indicator code as a limiting factor. The remaining edaphic variables evaluated $(\mathrm{N}, \mathrm{P}, \mathrm{C}$, and organic matter content) were within the optimal range for blueberry development.

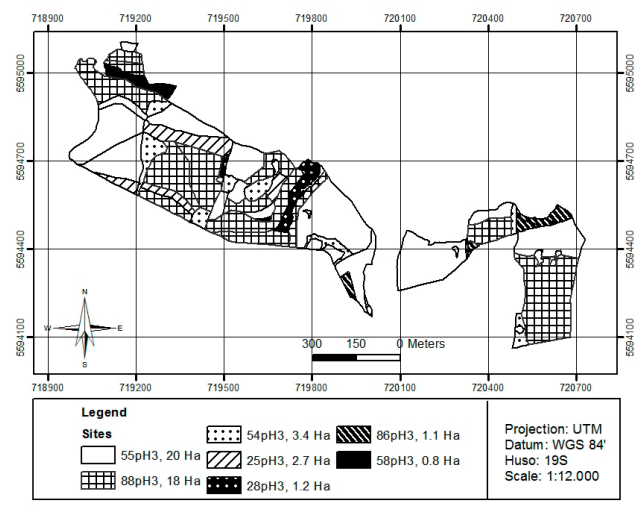

Figure 3. Sites in the study area (characterization described in Table 4).

The predominant site indicator was $55 \mathrm{pH} 3$, which accounted for $42 \%$ of the farm surface (Table 3). This site indicator corresponds to soil with medium texture (loam soil), a depth of $30-80$ $\mathrm{cm}$, the presence of seasonal hydromorphism in the middle stratum, and a moderately acidic $\mathrm{pH}$.

Suitability of the study area for the development and establishment of northern highbush blueberry

Four categories of land suitability were identified in the study area: high, moderate, low, and unsuitable. Sites with moderate suitability for the establishment and development of northern highbush blueberry were predominant $(60 \%$ of the surface area), followed by low suitability sites ( $20 \%$ of the surface area), high suitability sites $(12 \%$ of the surface area), and unsuitable sites (7.4\% of the surface area) (Figure 4 ).

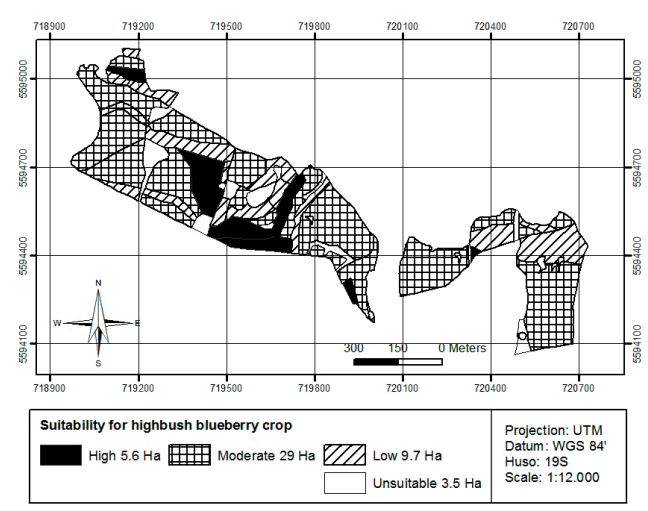

Figure 4. Suitability of sites within the study area for highbush blueberry cultivation.

Table 4. Characterization of the sites at the study farm and their surface area expressed as a percentage of the total.

\begin{tabular}{|c|c|c|c|c|c|}
\hline \multicolumn{4}{|c|}{ Sites } & \multicolumn{2}{|c|}{ Area } \\
\hline Site code & Texture-Depth ${ }^{1}$ & Hydromorphism & $\mathrm{pH}$ & ha & $\%$ \\
\hline $55 \mathrm{pH} 3$ & Medium-intermediate & Seasonal mid-level hydromorphism & Moderately acidic & 20.1 & 42.4 \\
\hline $88 \mathrm{pH} 3$ & Medium-deep & Moderate drainage & Moderately acidic & 18.3 & 38.1 \\
\hline $54 \mathrm{pH} 3$ & Medium-intermediate & Seasonal surface hydromorphism & Moderately acidic & 3.4 & 7.2 \\
\hline $25 \mathrm{pH} 3$ & Medium-shallow & Seasonal mid-level hydromorphism & Moderately acidic & 2.7 & 5.7 \\
\hline $28 \mathrm{pH} 3$ & Medium-shallow & Moderate drainage & Moderately acidic & 1.2 & 2.5 \\
\hline $86 \mathrm{pH} 3$ & Medium-deep & Seasonal deep hydromorphism & Moderately acidic & 1.1 & 2.3 \\
\hline $58 \mathrm{pH} 3$ & Medium-intermediate & Moderate drainage & Moderately acidic & 0.8 & 1.7 \\
\hline & & Total & & 47.54 & 100 \\
\hline
\end{tabular}

${ }^{1}$ Shallow: $0-30 \mathrm{~cm}$; Intermediate: $30-80 \mathrm{~cm}$ : Deep: $>80 \mathrm{~cm}$. 
Unsuitable areas. In areas identified as unsuitable $(7.4 \%$ of the surface area), depressed or mountainous districts prevent the establishment of blueberry. The susceptibility of depressed districts to waterlogging renders them unsuitable for blueberry cultivation. In mountainous districts, the slope exceeds $64.5 \%$; therefore, the areas are unsuitable for agriculture.

Low suitability areas. In low suitability areas ( $20 \%$ of the surface area), the establishment of blueberry is difficult, and the management of the crop may be complicated, expensive and can have negative impacts on the agroecosystem. These areas correspond to hilly districts (34.5 - 66\% slope) with soils that are considered suitable for silviculture (class VII) (Centro de Información de Recursos Naturales, 2002). In the present study, these districts co-occurred with soils having a limited depth (shallow to intermediate) and/or hydromorphic characteristics (seasonal mid-level or deep). Moreover, a moderately acidic $\mathrm{pH}$ represented a limiting factor throughout the entire farm area. For these reasons, these soils have low suitability for blueberry cultivation.

Moderate suitability areas. In these areas $(60 \%$ of the farm surface area), the establishment and development of blueberry are moderately difficult, and the productive potential of the species is suboptimal. Thus, soil characteristics must be corrected for cultivation. Various combinations of districts and soil characteristics were observed in these areas:

a) Flat districts ( $0-10.5 \%$ slope $)$ are considered to be moderately suitable for blueberry cultivation. These districts co-occurred with sites having optimal physical soil characteristics (soil depth $>80 \mathrm{~cm}$, with loamy texture, moderate drainage and moderately acidic $\mathrm{pH}$ ) and sites with limiting soil depth (intermediate, $<80$ $\mathrm{cm}$ or shallow, $<30 \mathrm{~cm}$ ) and/or hydromorphic characteristics (seasonal surface or deep). Moderately acidic $\mathrm{pH}$ was a limiting factor at all sites.
The soil $\mathrm{pH}$ would need to be reduced to values of 4.3 - 5 by sulfur application, the injection of sulfuric acid into the irrigation water, or the incorporation of pine needles into the planting ridges (Jimenez et al., 2005). Furthermore, at sites with shallow soils, ridges may be necessary to increase the effective depth of the soil (for instance, Instituto de Investigaciones Agropecuarias, 2010), or techniques such as tilling the B horizon may need to be applied (Lacey et al., 2001). Furthermore, the addition of sawdust to the ridges may be required to prevent waterlogging.

b) Inclined undulating districts ( $17.5-34.5 \%$ slope) are also considered to be moderately suitable for the establishment of blueberry. These districts were found to co-occur with sites having optimal physical edaphic characteristics and sites with limiting soil depth (intermediate or shallow) and/or hydromorphic characteristics (seasonal surface or deep). Moderately acidic $\mathrm{pH}$ was a limiting factor at all sites.

The cultivation of northern highbush blueberry at these sites would require management techniques to allow for cultivation on inclined terrain, such as the construction of terraces or infiltration ditches and the use of living barriers (Kosmas et al., 2008). As described in the preceding section (a), methods to reduce the soil $\mathrm{pH}$, increase the effective soil depth, or prevent waterlogging may be required.

c) Softly undulating districts (10.5 - 17.5\% slope) are considered ideal for blueberry cultivation. These districts co-occurred with sites having the following limiting characteristics: intermediate soil depth, seasonal hydromorphism in the middle stratum, and a moderately acidic $\mathrm{pH}$. The cultivation of northern highbush blueberry on these soils would require an increase in the effective soil depth, drainage management, and a reduction in soil $\mathrm{pH}$ to optimize the land for blueberry cultivation (using the methods described in section (a)) (Ferreyra et al., 2001). 
High suitability areas. These areas $(12 \%$ of the farm surface area) have high productive potential and optimal conditions for blueberry cultivation. The features that characterize these areas are softly undulating slopes (10.5 - 17.5\% slope), deep soils, and moderate drainage or seasonal deep hydromorphism that does not affect the roots of the plant. The only optimization that would be required by these soils is $\mathrm{pH}$ management (using the methods described in in the preceding section (a)).

The findings of the present study indicate that blueberry cultivation is possible on $72 \%$ of the farm surface, which includes areas of high and medium suitability. For much of this area (60\%), several management methods would be required to enable the cultivation of this crop. For the remaining area (12\%), only $\mathrm{pH}$ adjustment would be required.

The method used in the present study for the determination of suitability is simple and may be applied to any type of farm for which the required information is available.

\section{Acknowledgments}

The authors wish to acknowledge the Centro Regional de Innovación Hortofrutícola de Valparaíso (CERES) (Chile) for their assistance and support of this research.

\section{Resumen}

L. Vera, R. Montalba, L. Vieli, E. Jorquera, e I. González. 2015. Metodología para la determinación de la aptitud territorial para el cultivo de arándano alto del norte: caso de estudio en un predio en el sur de Chile. Cien. Inv. Agr. 42(3): 353-364. La selección de sitios adecuados para el cultivo es una estrategia clave en las plantaciones de arándanos. El objetivo de este estudio fue identificar zonas prediales con diferente aptitud para el establecimiento y manejo del cultivo de arándano en un predio en el sur de Chile. Para ello, se desarrolló una caracterización predial y posteriormente se aplicó una metodología de valoración de distritos y sitios según su aptitud. Esto permitió obtener valores numéricos de aptitud para cada unidad territorial identificada en el predio. Se identificaron cuatro categorías de aptitud en el predio en estudio: alta (12\% de la superficie), media ( $60 \%$ de la superficie), baja ( $20 \%$ de la superficie) y sin aptitud (7,4\% de la superficie). Las principales limitantes encontradas para el cultivo del arándano fueron las altas pendientes, la poca profundidad del suelo, la presencia de hidromorfismo y un $\mathrm{pH}$ muy elevado del suelo, considerando los requerimientos de bajo $\mathrm{pH}$ del cultivo del arándano. El método permitió determinar que el cultivo del arándano es posible en un $72 \%$ de la superficie del predio estudiado (zonas con alta y media aptitud), aplicando distintos manejos de suelo de acuerdo a las limitantes específicas de cada área.

Palabras clave: $\mathrm{pH}$, pendiente, variable limitante, ordenamiento territorial, capacidad de acogida

\section{References}

Ande, O. 2011. Soil suitability evaluation and management for cassava production in the derived Savanna Area of Southwestern Nigeria. International Journal of Soil Science 6:142-249.
Basheer-Salimia, R., M. Al-Amleh, and A. Mohamad. 2014. Palestinian Strategic Food Security via Land Suitability Analysis for Reclamation. Journal of Food Security 2: 27-32.

Beare, M., D. Coleman, D. Crossley, P. Hendrix, and E. Odum. 1995. A hierarchical approach to eval- 
uating the significance of soil biodiversity to biogeochemical cycling. Plant and Soil 170: 5-22.

Broll, G., B. Hiller, F. Bednorz, G. Müller, and T. Reineke. 2005.Guideline for Describing Soil Profiles in Mountain Ecosystems In: Broll, G. and Keplin, B. (eds). Mountain Ecosystems. Springer-Verlag. Berlin, Germany. 353 pp.

Buzeta, P. 1997. Chile: Berries para el 2000. Fundación Chile. Santiago, Chile. 133 pp.

Calatrava, J., J. Franco, and M. González. 2007. Analysis of the adoption of soil conservation practices in olive groves: the case of mountainous areas in southern Spain. Spanish Journal of Agricultural Research 5: 249-248.

Centro de Información de Recursos Naturales. 2002. Estudio Agrológico X Región. Descripciones de suelos. Materiales y símbolos. CIREN. Santiago, Chile. 412 pp.

Cosio, F., M. Negrón, J. Gastó, and J. Villate. 2007. Distritos y sitios de la provincia templada secoestival nubosa o Valparaíso: secano de la costa. Revista de la Ciencia del Suelo y Nutrición Vegetal 7:38-61.

Ferreyra, R., J. Peralta, A. Sadzawka, A. Muñoz, and J. Valenzuela. 2001. Efecto de la acidificación del sustrato y del agua de riego en la nutrición, desarrollo y producción de arándano ojo e conejo (Vaccinium ashei Reade). Agricultura Técnica 61: 452-458.

Food and Agriculture Organization of the United Nations. 2006. Guidelines for soil description. FAO. Rome, Italy. 98 pp.

Gastó, J., D. Subercaseaux y L. Vera. 2012. Ecology: an integrated science for the artificialization of nature. Cien. Inv. Agr. 39:397-410.

Gastó, J., P. Rodrigo, e I. Aranguiz. 2002. Ordenación Territorial, Desarrollo de Predios y Comunas Rurales. Pontificia Universidad Católica de Chile. Facultad de Agronomía e Ingeniería Forestal. LOM Ediciones. Santiago, Chile. 994 pp.

Instituto de Investigaciones Agropecuarias. 2010. Manejo de suelos para el establecimiento de huertos Frutales. INIA. Santiago, Chile. 128 pp.

Instituto Nacional de Estadísticas. 2007. VII Censo Agropecuario y Forestal. INE. Santiago, Chile. Available online at: www.censoagropecuario.cl (Website accessed: June 25, 2015).
Instituto Nacional de Estadísticas (INE). 2007. Región de Los Ríos. INE. Santiago, Chile. 15 pp.

Jimenez, M., F. Carpenter, R. Molinar, K. Wright, and K. Day. 2005. Blueberry research launches exciting new California Specialty crop. California Agriculture 59: 65-69.

Kosmas, C., N. Yassoglou, A. Kounalaki, and O. Kairis. 2008. Estructuras tradicionales y actuales para la conservación y cultivo de los suelos, Universidad Nova de Lisboa. Proyecto Lucinda. Land Care in Desertification Affected Areas. Lisboa, Portugal. 4 pp.

Lacey, S., P. Brennan, and J. Parekh. 2001. Deep may not be meaningful: Cost and effectiveness of various ripping tine configurations in a plantation cultivation trial in eastern Australia. New Forest 21: 231-248.

López, I., I. Valentine, M. Lambert, D. Hedderley, and P. Kemp. 2006. Plant functional groups in a heterogeneous environment. New Zealand Journal of Agricultural Research 49: 439-450.

Ministerio de Agricultura. 2015. Coyuntura Agrometeorológica. MINAGRI. Available online at: http://newsflash.asoex.cl/userfiles/file/346B coyuntura_agroclimatica_MAYO2015_vfinal. pdf (Website accessed: June 24, 2015).

Perverzev, V., and T. Litinova. 2008. Hydromorphism and Al-Fe-humus pedogenesis on sandy parent materials in the Kola Peninsula. Eurasian Soil Science 41: 677-685.

Reyes-Díaz, M., M. Alberdi, and M. Mora. 2009. Shortterm aluminum stress differentially affects the photochemical efficiency of photosystem II in highbush blueberry genotypes. Journal of the American Society for Horticultural Science 134: 14-21.

Robinson, D., I. Lebron, and H. Vereecken. 2009. On the definition of the natural capital of soils: a framework for description, evaluation, and monitoring. Soil Sci. Soc. Am. J. 73:1904-1911.

Sadzawka, A., M. Carrasco, R. Grez, M. Mora, H. Flores, and A. Neaman. 2006. Métodos de Análisis Recomendados para los Suelos de Chile. Instituto de Investigaciones Agropecuarias. Santiago, Chile.161 pp.

Shanshan, Z., T. XueDong, L. YaDong, and H. XiuRong. 2009. Effects of corn stalk and inorganic 
nitrogen amending soil on the growth and fruit of blueberry. Journal of Jilin Agriculture University 31:565-569.

Shepherd, T. 2000. Visual Soil Assessment. Volume 1. Field guide for cropping and pastoral grazing on flat to rolling country. Horizons.mw \& Landcare Research, Palmerston North.

Steubing, L., R. Godoy, and M. Alberdi. 2002. Métodos de Ecología Vegetal. Editorial Universitaria. Santiago, Chile. 345 pp.

USDA-U.S. Department of Agriculture. 2003. Guía para la evaluación de suelos y valoración de sitios. USDA, Washington D.C., USA. Available online at: http://www.nrcs.usda.gov/programs/ lesa/LESA\%20Guidebook_ESP.pdf (Website accessed: June 6, 2011).

Vélez, L., and J. Gastó. 2002. Metodología y Determinación de los Estilos Rurales en Escala Predial. In: Gastó, J., P. Rodrigo e I. Aránguiz. (eds.). Ordenación Territorial. Desarrollo de Predios y Comuna Rurales. LOM Ediciones Ltda. Santiago, Chile. $994 \mathrm{pp}$

Wu, J. and J. David. 2002. A spatially explicit hierarchical approach to modeling complex ecological systems: theory and applications. Ecological Modeling 153:7-26. 